\title{
Penerapan Sistem Informasi Akuntansi Pada Pondok Pesantren Di Kota Madiun
}

\author{
Siti Suharni ${ }^{1}$, Syarifah Ratih Kartika Sari ${ }^{2}$ \\ ${ }^{1}$ Fakultas Ekonomi, Universitas Merdeka Madiun, Jl.Serayu 79, Madiun, 63133 \\ E-mail: sitisuharni@unmer-madiun.ac.id \\ ${ }^{2}$ Fakultas Ekonomi, Universitas Merdeka Madiun, Jl.Serayu 79, Madiun, 63133 \\ E-mail: syarifah@unmer-madiun.ac.id
}

\begin{abstract}
Accountancy Information System is a system made by human beings consists of components in an organization to accomplish a goal, e.g. presenting information. Therefore, employing information system in pondok pesantren is absolutely necessary. Besides for adding efficiency and effectiveness of financial operational in pesantren, it also helps presenting aiding progress report given. Information resulted by Accountancy Information System holds an essential role. It can be used to monitoring, controlling medium, and managing all activity and financial operational activity of pondok pesantren in order to be running well. This st udy has general objective, e.g. understanding how good system for pesantren is. While specific objective of this study is understanding design of accountancy information system of Madiun City Boarding School. This study employs descriptive-qualitative approach that aims to describe object of research by collecting data. Data are collected through observation, interview, and documentation. Analysis of this study includes analysis on organizational structure, analysis of document used, and analysis of procedure implemented.
\end{abstract}

Keywords —: Design; Accountancy Information System; Pondok Pesantren.

\section{PENDAhUluaN}

Memasuki era tahun 2000-an pesantren tumbuh dan berkembang dengan sangat pesat. Menurut data dari kemenag RI tahun 2016 jumlah Pesantren di Indonesia mencapai 28,961 dengan jumlah santri sebanyak 4,028,660. Banyak pesantren baru yang tidak hanya berorientasi pada dunia pendidikan namun juga di bidang usaha. Hal ini karena pesantren mulai tergerak untuk melatih santrinya berwirausaha. Puspitasari dalam penelitiannya yang berjudul Studi Komparasi Model Pengembangan Kecakapan Hidup (Life Skill) Santri Di Pondok Pesantren An-Nashr (Tarbiyatul Banin) Cirebon Dengan Santri Di Pondok Pesantren Sidogiri Pasuruan, mengemukakan bahwa "Pada masa kini Pendidikan pesantren diselenggarakan untuk meningkatkan kualitas daya pikir, daya kalbu dan daya fisik peserta didik sehingga yang bersangkutan memiliki lebih banyak pilihan dalam kehidupan, baik pilihan kesempatan untuk melanjutkan pendidikan yang lebih tinggi, pilihan kesempatan untuk bekerja maupun pilihan untuk mengembangkan dirinya. Untuk mencapai tujuan tersebut, pendidikan pesantren perlu memberikan bekal dasar. kemampuan kesanggupan dan keterampilan kepada peserta didik agar mereka siap menghadapi berbagai kehidupan nyata. Dengan adanya upaya pembelajaran kecakapan diharapkan ke depan muncul usaha perekonomian baru di masyarakat melalui pemanfaatan potensi lokal di bawah binaan pesantren.

Namun berkembang pesatnya Pesantren di Indonesia ini lebih disebabkan oleh kesadaran religious dari masyarakat Indonesia. Mereka mulai menyadari bahwa pendidikan keagamaan sangatlah penting untuk membentuk generasi yang beretika moral. Sesuai dengan Undang-undang Nomor 20 tahun 2003 tentang Sistem Pendidikan Nasional, dalam pasal 3 yang berbunyi: Pendidikan Nasional berfungsi mengembangkan kemampuan dan membentuk watak serta peradaban bangsa yang bermartabat dalam rangka mencerdaskan kehidupan bangsa, bertujuan untuk berkembangnya potensi peserta didik agar menjadi manusia yang beriman dan bertakwa kepada Tuhan Yang Maha Esa, berakhlak mulia, sehat, berilmu, cakap, kreatif, mandiri, dan menjadi warga negara yang demokratis serta bertanggung jawab. Ketentuan ini tentu saja sudah berlaku dan diimplementasikan di Pesantren.

Untuk pesantren yang tak hanya bergerak di bidang pendidikan, tentu saja laporan kegiatan ataupun laporan keuangan bukanlah menjadi hal yang baru. Namun bagi Lembaga pesantren yang hanya bergerak di dunia pendidikan terutama Pesantren kecil yang berdiri di plosok daerah, laporan-laporan seperti ini merupakan suatu hal yang baru dan bisa dikatakan sebagai tindakan ketidakpercayaan ataupun ketidak ikhlasan atas bantuan yang diberikan. Menurut mereka bantuan yang diberikan itu digunakan untuk apapun sudah mutlak menjadi hak dari pesantren tersebut, dan tidak perlu dilaporakan. Padahal jika dilihat dar sudut pandang pemerintah, laporan kegiatan ataupun laporan keuangan merupakan suatu hal yang sangat penting. Mahmudi (2007:11) mengungkapkan bahwa laporan keuangan adalah informasi yang disajikan untuk membantu stakeholders dalam membuat keputusan sosial, politik dan ekonomi sehingga keputusan yang diambil bisa lebih berkualitas.

Pondok pesantren yang bergerak di bidang pendidikan dan bisnis bisa disebut dengan pondok modern, sedang pondok yang berfokus pada pendidikan saja sering disebut dengan pondok salaf. Diantara kedua jenis pesantren tersebut pemerintah biasanya menawarkan bantuan ke pesantren-pesantren salaf di seluruh Indonesia dengan syarat dan ketentuan yang berlaku. Peneliti 
tertarik untuk meneliti pesantren salaf yang dalam hal ini sebagian besar masih belum mempunyai sistem informasi akuntansi sebagai landasan kegiatan operasional keuangan. Pondok salaf dalam menjalankan kegiatan operasional keuangan biasanya tidak berdasarkan prosedur-prosedur baku yang tertulis, namun berdasarkan langkah-langkah yang dilakukan secara turun temurun. Walaupun sebagian sudah mempunyai prosedur baku yang tertulis. Berlandaskan azas kepercayaan, dimana pihak yang diamanati memegang keuangan pesantren maka dia diberi kepercayaan penuh dalam menjalankan kegiatan operasional.

Ada banyak faktor religious yang melandasi jalannya kegiatan operasional pesantren. Namun semakin berkembangnya zaman dan majunya teknologi di era modern ini, pesantren perlu untuk ikut berkembang mengikuti arus perubahan zaman. Yang mana di era digital ini, sangat dibutuhkan infomasi yang dihasilkan oleh sistem informasi akuntansi. Sekecil apapun organisasi itu diperlukan suatu aturan-aturan maupun kebijakan-kebijakan yang baku dan tertulis. Menurut Mulyadi (2010:3), sistem informasi akuntansi adalah organisasi formulir, catatan, dan laporan yang dikoordinasi sedemikian rupa untuk menyediakan informasi keuangan yang dibutuhkan oleh manajemen guna memudahkan pengelolaan organisasi. Jadi bisa disimpulkan bahwa sistem informasi akuntansi itu memudahkan proses yang terjadi dalam kegiatan operasional, sehingga sangat membantu dalam pembuatan laporan kegiatan atau laporan keuangan bagi pesantren.

Yang mempunyai makna "memelihara hal-hal lama yang bagus dan mengambil hal-hal baru yang lebih bagus". Sesuai dengan kaidah diatas maka bisa dikatakan bahwa sistem informasi akuntansi bagi pesantren merupakan hal baru yang lebih bagus dan bisa diambil untuk dijadikan suatu landasan dalam melakukan kegiatan operasional keuangan pesantren.

Menurut Widjajanto (2001:4) sistem akuntansi adalah susunan berbagai formulir, catatan, peralatan, termasuk komputer dan perlengkapan serta alat komunikasi, tenaga pelaksananya dan laporan yang terkoordinasi secara erat yang didesain untuk mentransformasikan data keuangan menjadi informasi yang dibutuhkan manajemen. Menurut Jogiyanto (2003:225), sistem informasi akuntansi adalah sistem informasi yang merekam dan melaporkan transaksi bisnis aliran dana dalam organisasi, dan menghasilkan laporan keuangan. Sedang menurut Wahyono (2004:17), sistem informasi akuntasnsi merupakan suatu sistem yang dibuat oleh manusia yang terdiri dari komponen-komponen dalam organisasi untuk mencapai sebuah tujuan yaitu penyajian informasi. Oleh sebab itu penggunaan sistem informasi pada pondok pesantren sangatlah dibutuhkan selain menambah efektifitas dan efisiensi operasional keuangan pesantren juga sebagai sarana membantu proses pelaporan pertanggungjawaban bantuan yang diberikan. Informasi yang dihasilkan oleh sistem informasi akuntansi memegang peranan yang penting. Sistem informasi akuntansi itu sendiri dapat digunakan untuk sarana pengawasan, pengendalian, dan pengaturan segala aktifitas dan kegiatan operasional keuangan pondok pesantren agar berjalan sesuai dengan apa yang telah ditetapkan.

Karena peran penting dari sistem informasi akuntansi bagi kemaslahatan pesantren sebagai pengawas atas jalannya prosedur-prosedur kegiatan operasional keuangan pesantren, maka perlu untuk disusun sebuah sistem yang sederhana dan baik yang sesuai dengan kaidah akuntansi dan kondisi pesantren tersebut. Sistem informasi akuntansi merupakan suatu kegiatan input, proses dan output data yang dilakukan oleh perusahaan. Hasil data akhir yang telah diproses sistem informasi akuntansi bertujuan sebagai pelaporan bagi pihak internal dan eksternal guna melakukan pengendalian perusahaan (Putu, 2012). Bisa ditarik kesimpulan jika sistem informasi akuntansi sangat penting dalam membantu kelancaran kegiatan akuntansi untuk suatu organisasi baik besar maupun kecil, khususnya pondok pesantren.

Mayoritas Pondok Pesantren di Kota Madiun masih belum memiliki sistem informasi akuntansi yang baku dan tertulis dalam menyusun laporan keuangan atau laporan kegiatan. Walaupun jika dilihat dari segi bangunan dan prasarana masih tergolong sedang, namun dalam setiap transaksi yang terjadi melibatkan nominal yang tidak sedikit. Meski demikian dalam proses penyusunan laporan keuangan atau laporan kegiatan masih berdasarkan prosedur-prosedur yang dilakukan secara turun temurun. Sehingga dalam proses pembuatan laporan keuangan atau laporan pertanggungjawaban masih secara sederhana, dokumendokumen pendukung dalam proses penyusunan laporan tersebutpun belum menggunakan bukti transaksi tersendiri antara transaksi kas keluar dan transaksi kas masuk. Sehingga perlu pembenahan dan perbaikan atas proses dalam setiap siklus yang terjadi pada kegiatan keuangan pondok pesantren tersebut.

\section{A. Sistem Informasi}

a. Pengertian Sistem

Sistem adalah sekelompok elemen-elemen yang saling terintegrasi dengan maksud yang sama untuk mencapai suatu tujuan. Berikut ini beberapa pengertian sistem yang dikemukakan oleh beberapa ahli, diantaranya:

i. Krismiaji (2002:29) mendefinisikan sistem sebagai serangkaian komponen yang dikoordinasikan untuk mencapai serangkaian tujuan.

ii. Mulyadi (2008:5), sistem adalah suatu jaringan prosedur yang dibuat menurut pola terpadu untuk melaksanakan kegiatan pokok perusahaan.

iii. Hall (2007:5) juga berpendapat bahwa, sistem adalah sekelompok dua atau lebih komponen- komponen yang saling berkaitan (subsistem-subsistem yang bersatu untuk mencapai tujuan yang sama).

Berdasarkan definisi-definisi diatas maka dapat ditarik sebuah kesimpulan bahwa sistem merupakan serangkaian unsur-unsur yang saling berkaitan dan bekerjasama menyelesaikan suatu sasaran tertentu untuk mempermudah bagi pembuat maupun yang pengguna sistem tersebut guna mencapai tujuan yang telah ditentukan sebelumnya.

b. Pengertian Informasi

Informasi adalah kombinasi antara prosedur kerja, informasi, orang, dan teknologi informasi yang diorganisasikan untuk mencapai tujuan dalam sebuah organisasi (Alter, 1992). Dibawah ini beberapa pengertian informasi menurut para ahli: 
Website : http://ekomaks.unmermadiun.ac.id/index.php/ekomaks

i. Mcloed (2001:15) berpendapat bahwa informasi adalah data yang telah diproses, atau data yang memiliki arti.

ii. Willkinson (1995:6) juga mengemukakan bahwa informasi sebagai data yang telah diproses sehingga bentuknya berubah dan nilainya semakin tinggi dan berguna untuk mencapai tujuan tertentu.

Bisa ditarik suatu kesimpulan bahwa informasi merupakan hasil dari pengolahan data dalam suatu bentuk yang lebih berguna dan berarti bagi penerimanya untuk menggambarkan suatu kejadian-kejadian yang nyata (fakta) yang digunakan untuk pengambilan suatu keputusan. Dengan kata lain, informasi adalah fakta yang mempunyai arti dan berguna untuk mencapai tujuan tertentu.

c. Sistem Informasi dan Sistem Akuntansi

Sebuah sistem informasi mengumpulkan, memproses, menyimpan, menganalisis, dan menyebarkan informasi untuk tujuan yang spesifik (Turban, McClean dan Wetherbhe, 1999).

Sistem informasi juga merupakan kumpulan dari bagian-bagian yang saling berkaitan yang beroperasi bersama untuk mencapai beberapa ssasaran atau maksud. Sistem yang diciptakan oleh para analis dan manajer guna melaksanakan tugas khusus tertentu yang sangat esensial bagi berfungsinya organisasi. Secara teknis sistem informasi dapat didefinisikan sebagai sekumpulan komponen yang saling berhubungan, mengumpulkan, memproses, menyimpan, dan mendistribusikan informasi untuk menunjang pengambilan keputusan, pengawasan dalam suatu organisasi, membantu menganalisis permasalahan, menggambarkan hal-hal rumit, dan menciptakan produk baru (Scott, 2004:4).

Sistem akuntansi merupakan gabungan dari kata sistem dan akuntansi. Namun menurut Mulyadi (2010:3) sistem akuntansi adalah organisasi formulir, catatan, dan laporan yang dikoordinasikan sedemikian rupa untuk menyediakan informasi keuangan yang dibutuhkan oleh pihak manajemen guna memudahkan mengelola perusahaan. Narko (2007), menyatakan bahwa sistem akuntansi diartikan sebagai jaringan yang terdiri dari formulir-formulir, catatan-catatan, prosedur-prosedur alat-alat dan sumber daya manusia dalam rangka menghasilkan informasi pada suatu organisasi untuk keperluan pengawasan, operasi maupun kepentingan pengambilan keputusan bisnis bagi pihak-pihak yang berkepentingan.

Sistem akuntansi Pondok Pesantren satu dengan Pondok Pesantren yang lain berbeda- beda. Hal ini disebabkan karena kebutuhan dan besarnya Pondok Pesantren tersebut juga berbeda antara satu dengan yang lain. Namun pada dasarnya sistem akuntansi mempunyai fungsi yang sama.

\section{B. Sistem Informasi Akuntansi}

Sistem informasi akuntansi menurut Wilkinson and Cerulo (1995, p.5-6) merupakan struktur yang menyatu dalam suatu entitas, yang menggunakan sumber daya fisik dan komponen lain, untuk merubah data transaksi keuangan / akuntansi menjadi informasi akuntansi dengan tujuan untuk memenuhi kebutuhan akan informasi dari para pengguna atau pemakainya.

George H. Bodnar dan William S. Hopwood berpendapat dalam bukunya yang diterjemahkan oleh Jusuf, A.A (1996), sistem informasi akuntansi ialah kumpulan sumber daya, seperti manusia dan peralatan, yang diatur untuk mengubah data menjadi informasi akuntansi. Informasi ini dikomunikasikan kepada para penggunanya untuk pengambilan keputusan.

Menurut Krismiaji (2002: 4-5) sistem informasi akuntansi adalah sebuah sistem yang memproses data dan transaksi guna menghasilkan informasi yang bermanfaat untuk merencanakan, mengendalikan, dan mengoperasikan bisnis. Untuk dapat menghasilkan informasi yang diperlukan oleh para pembuat keputusan, sistem informasi akuntansi harus menjalankan tugastugas sebagai berikut:

1) Mengumpulkan transaksi dan data lain dan memasukkannya kedalam system.

2) Memproses data transaksi.

3) Menyimpan data untuk keperluan di masa dating.

4) Menghasilkan informasi yang diperlukan dengan memproses laporan, atau memungkinkan para pemakai untuk melihat sendiri data yang tersimpan dikomputer.

5) Mengendalikan seluruh proses sedemikian rupa sehingga informasi yang dihasilkan akurat dan dapat dipercaya.

\section{Fungsi Sistem Informasi Akuntansi}

Menurut Yuli (2004) terdapat enam fungsi dalam sistem informasi akuntansi, antara lain:

a. Pengumpulan Data atau Transaksi

Pengumpulan data atau transaksi terdiri dari tahap penangkapan data. Kemudian data akan dicatat ke dalam formulirformulir yang dikenal sebagai dokumen sumber. Dokumen tersebut biasanya disahkan atau divalidasi untuk menjamin kecermatan dan dikelompokkan agar bisa ditempatkan pada kategori yang telah ditentukan. Setelah itu dapat dilakukan pemrosesan data.

b. Pemrosesan Data atau Transaksi

Data atau transaksi untuk dapat menjadi suatu informasi yang berharga haruslah diproses terlebih dahulu. Pemrosesan data dapat dilakukan dengan berbagai cara, hal itu tergantung dari informasi yang dibutuhkan. Data yang terkumpul bisa diikhtisarkan dengan menjumlahkan transaksi yang sejenis, terkadang data dialihkan ke dokumen atau media lain. Data juga bisa ditumpuk dengan mengumpulkan transaksi yang sejenis dalam satu dokumen, kemudian dipilih untuk disusun berdasarkan karakteristik tertentu. 
Website : http://ekomaks.unmermadiun.ac.id/index.php/ekomaks

\section{c. Pemanajemenan Data}

Dalam manajemen data terdapat tiga tugas utama, yaitu penyimpanan, pemutakhiran, dan pengambilan ulang. Penyimpanan data bisa dilakukan dalam arsip, file, atau database dengan cara yang relative permanen atau bersifat sementara yang menunggu permrosesan lebih lanjut. Pemutakhiran disesuaikan dengan data yang tersimpan agar mencerminkan operasi, peristiwa, dan keputusan yang terbaru. Pengambilan ulang merupakan usaha mengambil kembali data yang tersimpan untuk diproses lebih lanjut agar dapat menjadi suatu informasi yang berguna.

d. Pengendalian dan Pengamanan Data

Data yang dimasukkan ke dalam pemrosesan bisa saja hilang, rusak, salah, dicuri, atau dipalsukan. Untuk itu salah satu tugas penting sistem informasi akuntansi adalah melindungi dan menjamin keakuratan data termasuk informasinya. Alat kendali dan cara pengamanan yang dapat dilakukan adalah otorisasi, rekonsiliasi, verifikasi, dan tinjauan.

e. Pengadaan Informasi

Tugas akhir dari sistem informasi akuntansi yaitu penyampaian informasi kepada pemakai. Pelaporan meliputi penyiapan laporan dari data yang telah diproses dan disimpan. Sedangkan pengkomunikasian merupakan penyajian laporan sedemikian rupa agar berguna bagi pemakai informasi.

f. Pertimbangan Perancangan Sistem Pemrosesan

Perancangan sistem seharusnya mencerminkan prinsip-prinsip organisasi.

Dasar-dasar yang perlu diperhatikan dalam prioritas perancangan sistem adalah sebagai berikut:

a. Tujuan dalam perencanaan sistem dan usulan proyek seharusnya dicapai untuk menghasilkan kemajuan dan kemampuan sistem yang lebih besar.

b. Mempertimbangkan trade-off yang memadai antara manfaat dari tujuan perancangan sistem dengan biaya yang dikeluarkan.

c. Berfokus pada permintaan fungsional sistem.

d. Melayani berbagai macam tujuan.

e. Perancangan sistem memperhatikan keberadaan dari pengguna sistem.

\section{Komponen Sistem Informasi Akuntansi}

Marshall dan John (2015:11) mengemukakan bahwa komponen dari sistem informasi akuntansi ada enam, yaitu:
a. Orang
Orang yang mengoperasikan dan menjalankan fungsi sistem.

b. Prosedur

Prosedur dan instruksi baik manual maupun terotomatisasi yang terlibat di dalam kegiatan pengumpulan, pemrosesan, dan penyimpanan data mengenai kegiatan organisasi.

c. Data

Data mengenai organisasi dan proses bisnis dari organisasi.

d. Perangkat Lunak

Perangkat lunak yang digunakan untuk mengolah data organisasi.

e. Infrastruktur Teknologi Informasi

Infrastruktur teknologi informasi yang mencakup komputer-komputer, perangkat jaringan komunikasi dan perangkat pendukung yang digunakan untuk mengumpulkan, memproses, menyimpan, dan mentransmisikan data serta informasi.

f. Pengendalian Internal dan Langkah Pengamanan

Pengendalian yang dilakukan untuk menjaga keamanan data di dalam sistem informasi akuntansi.

\section{E. Perancangan Sistem Informasi Akuntansi}

Menurut Mcleod (2001:238), rancangan sistem adalah penentuan proses dan data yang diperlukan oleh sistem baru. Jadi dapat disimpulkan bahwa dapat disimpulkan bahwa perancangan sistem adalah penentuan kebutuhan dan spesifikasi sistem berdasarkan analisis yang dilakukan untuk pengembangan sistem yang baru.

Menurut Jogiyanto (2005:35), ada beberapa alasan yang mendasari sebuah perancangan sistem, antara lain:

a. Adanya permasalahan (problem) yang timbul di sistem yang lama.

Permasalahan yang timbul dapat berupa:

1. Ketidakberesan dalam sistem yang lama tidak beroperasi sesuai dengan yang diharapkan, baik itu karena banyak kecurangan yang terjadi, kesalahan-kesalahan yang tidak disengaja yang juga dapat menyebabkan kebenaran dari data kurang terjamin, ataupun tidak efisiennya operasi, dan tidak ditaatinya kebijaksanaan manajemen yang telah ditetapkan.

2. Pertumbuhan organisasi yang menyebabkan kebutuhan informasi yang semakin luas, volume pengelolaan data semakin meningkat, perubahan prinsip akuntansi yang baru.

b. Untuk meraih kesempatan (opportunity), berupa peluang-peluang pasar, menarik konsumen dan peluang-peluang bisnis 
Website : http://ekomaks.unmermadiun.ac.id/index.php/ekomaks

lainnya dari perkembangan teknologi.

c. Adanya instruksi (directive) dari atas pimpinan ataupun dari luar organisasi, seperti misalnya peraturan pemerintah.

\section{F. Langkah-langkah Perancangan Sistem Informasi Akuntansi}

Sistem informasi akuntansi harus mengikuti perkembangan kebutuhan informasi yang berjalan sesuai dengan berkembangnya perusahaan dan perkembangan teknologi(alat untuk memproses data), untuk itu diperlukan penyusunan kembali sistem yang baru. Menurut Jogiyanto (2002: 35-36), langkah-langkah penyusunan sistem informasi akuntansi terdiri dari beberapa tahap berikut:

a. Analisis sistem yang ada

Langkah ini dimaksudkan untuk mengetahui kekuatan dan kelemahan sistem yang berlaku. Analisis ini dilakukan dengan penelitian (survey) sistem yang berlaku. Data yang dikumpulkan dalam penelitian, adalah:

1. Analisis laporan keuangan yang digunakan saat ini,

2. Analisis transaksi,

3. Analisis catatan pertama,

4. Analisis catatan terakhir.

b. Perancangan sistem informasi akuntansi

Perancangan sistem dalam suatu entitas merupakan suatu kegiatan menyusun sistem yang baru untuk menggantikan sistem yang lama secara keseluruhan atau memperbaiki sistem yang telah ada. Beberapa hal yang membuat sistem lama perlu diganti dengan sistem yang baru atau diperbaiki, yaitu:

1. Adanya permasalahan-permasalahan yang timbul dalam sistem yang lama.

2. Untuk meraih kesempatan.

3. Adanya instruksi-instruksi.

Sedang menurut Mcleod (2001: 236), tahap analisis adalah sebagai berikut:

1. Mengumumkan penelitian.

2. Mengorganisasikan proyek.

3. Mendefinisikan kebutuhan informasi

4. Mendefinisikan kriteria kinerja sistem.

5. Menyiapkan usulan rancangan.

6. Menerima atau menolak rancangan.

Menurut Mcleod (2001: 238), langah-langkah tahap rancangan adalah:

1. Menyiapkan rancangan sistem yang baru.

2. Mengindentifikasi berbagai alternative konfigurasi sistem.

3. Mengevaluasi berbagai alternative konfigurasi.

4. Memilih konfigurasi terbaik.

5. Menyiapkan usulan penerapan.

6. Menyetujui atau menolak penerapan sistem.

Maka dapat ditarik kesimpulan bahwa perancangan sistem informasi adalah merupakan suatu kegiatan penyiapan spesifikasi rancangan untuk menyusun sistem baru atau mengubah sistem lama agar menjadi lebih baik.

\section{G. Penerapan Sistem Informasi Akuntansi}

Penerapan sistem (system implementation) merupakan tahap peletakan sistem agar siap untuk dioperasikan. Perencanaan dasar dalam kegiatan penerapan antara lain:

a. Persiapan implementasi sistem

Implementasi sistem sangat ditentukan oleh perencanaan yang dibuat untuk pelaksanaan implementasi sistem. Kesuksesan pengembangan sistem besar pengaruhnya ditentukan oleh perencanaan implementasi yang disusun dengan sebaik-baiknya dan dilaksanakan dengan semaksimal mungkin.

b. Pendidikan dan pelatihan karyawan

Dalam hal ini karyawan dapat digolongkan menjadi karyawan pemakai informasi dan karyawan pelaksana sistem, yang mana keduanya harus mengikuti kegiatan pendidikan dan pelatihan atas sistem yang baru.

c. Konversi sistem, terdiri dari:

1. Konversi langsung

Penerapan sistem baru secara langsung dan menghentikan segera pemakaian sistem lama.

2. Konversi paralel

Implementasi sistem baru secara bersamaan dengan pemakaian sistem yang lama selama jangka waktu tertentu.

3. Konversi modular (pendekatan pilot project)

Implementasi sistem baru ke dalam organisasi secara sebagian-sebagian.

4. Konversi Phase-in

Hampir sama dengan konversi modular, yang membedakan adalah pada konversi modular membagi organisasi 
Website : http://ekomaks.unmermadiun.ac.id/index.php/ekomaks

untuk implementasi sistem baru, sedang phase-in yang dibagi adalah sistemnya sendiri.

\section{H. Manfaat Sistem Informasi Akuntansi}

Wilkinson (2000:5), mengemukakan pendapatnya bahwa tujuan utama dari sistem informasi akuntansi adalah menyediakan informasi akuntansi untuk berbagai pengguna yaitu internal users seperti manajer atau external users seperti pelanggan. Tiga tujuan spesifik yang dapat membantu tercapainya tujuan utama, adalah sebagai berikut:

a. Mendukung operasi dari hari ke hari.

b. Mendukung pembuatan keputusan yang dilakukan oleh pengambil keputusan intern.

c. Memenuhi kewajiban sehubungan dengan pengelolaan.

Menurut Daranatha (2009:35), sistem informasi bagi penggunanya membantu mereka melakukan tugas mereka dengan efisien dan efektif, namun harus memenuhi tiga tujuan umum penyusunan sistem informasi akuntansi, antara lain:

a. Untuk memperbaiki informasi yang diberikan oleh sistem dalam kualitas, ketepatan waktu atau struktur dan informasi tersebut.

b. Untuk memperbaiki pengendalian akuntansi dan pengecekan intern, maksudnya memperbaiki daya andal informasi akuntasi dan menyediakan catatan yang lengkap sebagai pertanggungjawaban dalam melindungi harta perusahaan.

c. Untuk menurunkan biaya dalam menyelenggarakan catatan akuntansi Ketiga tujuan tersebut haruslah dipertimbangkan pada waktu menyusun suatu sistem informasi akuntansi, supaya salah satu tujuan diatas diharapkan tidak ada yang terlewatkan. Sehingga sistem informasi akuntansi yang efisien dan efektif dapat memberikan informasi yang handal dan dapat menyediakan informasi yang berkualitas bagi pihak-pihak yang membutuhkan. Bebas dari kesalahan, tidak bias, dan jelas maksud dan tujuannya. Diperlukan data yang benar dan akurat untuk menghasilkan informasi yang mempunyai karakteristik- karakteristik tersebut.

\section{METODOLOGI PENELITIAN}

\section{A. Jenis penelitian}

Jenis penelitian yang digunakan dalam penelitian ini yaitu kualitatif dengan pendekatan deskriptif. Menurut Moeloeng (20007:6), penelitian kualitatif adalah penelitian yang bermaksud untuk memahami fenomena tentang apa yang dialami oleh subjek penelitian misalkan perilaku, persepsi, motivasi, tindakan, dan lain-lain secara holistik, dan dengan cara deskripsi dalam bentuk kata-kata dan bahasa, pada suatu konteks khusus yang alamiah dan dengan memanfaatkan metode alamiah.

Peneliti menggunakan metode penelitian kualitatif karena ingin menerapkan Sistem Informasi Akuntansi pada Pondok Pesantren, dalam hal ini pada Pondok Pesantren di Kota Madiun.

\section{B. Subjek dan Objek Penelitian}

a. Subjek Penelitian

Subjek dari penelitian ini adalah wawancara lansung dengan pihak yang memiliki kewenangan dan mengetahui tentang prosedur dalam sitem informasi akuntansi pondok, yaitu :

1. Pengasuh Pondok Pesantren

2. Ketua / Lurah Pondok Pesantren

3. Pengurus Pondok Pesantren

4. Bendahara Pondok Pesantren

b. Objek Penelitian

Objek yang akan diteliti dari penelitian ini adalah Sistem Informasi Akuntansi Pondok, lebih tepatnya berupa:

1. Laporan Keuangan Pondok

2. Prosedur - prosedur yang berlaku pada Pondok Pesantren

\section{Teknik Pengumpulan Data}

Dalam penelitian ini untuk memperoleh data yang relevan, maka teknik yang dipakai dalam pengumpulan data, adalah teknik interview atau wawancara dan teknik dokumentasi. Teknik yang digunakan oleh peneliti untuk mendapatkan data yaitu :

a. Teknik interview atau wawancara, menurut Jogiyanto (2007:93) wawancara (interview) adalah komunikasi dua arah untuk mendapatkan data dari responden. Wawancara (interview) dapat berupa personal (personal interview), wawancara intersep (intercept interview), dan wawancara telepon (telephone interview).mtode yang digunakan adalah wawancara personal (personal interview) yaitu wawancara dilakukan dengan tanya jawab dengan pihak Pesantren secara langsung.

$b$. Teknik dokumentasi, merupakan teknik pengumpulan data dengan mencari data mengenai hal-hal atau variable yang berupa catatan, transkip, buku, surat kabar, majalah, prasasti, notulen rapat, agenda, dan sebagainya (Arikunto, 2006:231). Metode yang digunakan untuk mengumpulkan data yang telah tersedia pada Pesantren yang bersangkutan. Dalam penelitian ini, dokumen-dokumen yang menjadi objek data dalam penelitian adalah dokumen yang digunakan dan yang dihasilkan oleh Pesantren tersebut. 
Website : http://ekomaks.unmermadiun.ac.id/index.php/ekomaks

\section{Metode Analisis Data}

Metode analisis yang digunakan dalam penelitian ini adalah teknik analisis deskriptif. Yaitu metode yang sifatnya menguraikan, menggambarkan, membandingkan, suatu data dan keadaan serta menerangkan suatu keadaan sedemikian rupa sehingga dapat ditarik kesimpulan.

Metode analisis yang digunakan penelitian ini menggunakan teori yang dipaparkan oleh Mcleod (2001: 236). Menurut pendapatnya langkah-langkah penyusunan sistem informasi akuntansi terdiri dari beberapa tahap berikut:

a. Tahap analisis

1. Mengumumkan penelitian,

2. Mengorganisasikan proyek,

3. Mendefinisikan kriteria kinerja sistem,

4. Menyiapkan usulan rancangan,

5. Menerima atau menolak rancangan.

b. Tahap rancangan

1. Menyiapkan rancangan sistem yang baru,

2. Mengindentifikasi berbagai alternative konfigurasi sistem,

3. Mengevaluasi berbagai alternative konfigurasi,

4. Memilih konfigurasi terbaik,

5. Menyiapkan usulan penerapan,

6. Menyetujui atau menolak penerapan sistem.

\section{III.HASIL PENELITIAN DAN PEMBAHASAN}

\section{A. Analisis struktur organisasi dan Job Description}

Dalam setiap organisasi pemberian tanggungjawab disesuaikan dengan pemisahan tugas yang telah ditetapkan. Begitu pula dengan Pondok Pesantren diKota Madiun, dimana dalam transaksi penerimaan kas dan pengeluaran kas harus mendapat otorisasi oleh pihak terkait, dalam hal ini pengasuh atau lurah pondok. Prosedur yang digunakanpun cukup baik, namun terdapat kelemahan yang perlu untuk dibenahi yaitu dalam struktur organisasi, penerimaan kas dan pengeluaran kas dilakukan oleh satu petugas yaitu bendahara sebagai penerima dan pencatat. Walaupun di Pondok Pesantren ini memiliki dua orang bendahara, namun tugas dari masing-masing orang sama. Hal ini yang menjadi titik kelemahan dari struktur orgnasisasi ini, tidak ada pemisahan antara tugas dalam pencatatan dan penyimpanan kas.

Seharusnya terdapat pemisahan di dalam tugas pencatatan dan penyimpanan kas pada bendahara yaitu bagian administrasi sebagai fungsi pencatat dan bendahara sebagai fungsi penyimpan sehingga nanti akan terjadi saling mengecek (cross check) diantara fungsi-fungsi yang terlibat. Akan lebih baik jika orang yang bertugas sebagai administrasi adalah orang yang berkompeten dibidang akuntansi. Jadi bendahara umum yang menyimpan kas, sedang bagian administrasi sebagai pencatat. Tugas utama bagian administrasi ialah membukukan seluruh aktivitas ekonomi yang terjadi di pondok secara sistematis, periodic yang mana nantinya akan menghasilkan sebuah laporan keuangan yang mudah untuk dipahami oleh berbagai pihak, baik internal maupun eksternal pondok.

Karena tugas dari administrasi yaitu: mencatat, memeriksa semua transaksi yang berhubungan dengan keuangan pondok. Jadi ketika terdapat kas masuk atau keluar, dicatat kemudian diperiksa kembali otorisasinya, catatan transaksinya apakah telah sesuai sebagaimana mestinya dicatat pada akun yang tepat. Membuat laporan keuangan triwulanan dan laporan tahunan yang terdiri dari laporan posisi keuangan, laporan aktivitas, dan catatan atas laporan keuangan. Serta bersama dengan bendahara melaporkan laporan keuangan pondok kepada pengasuh.

Berdasarkan uraian diatas maka rekomendasi Job Description dari Administrasi ialah:

a. Melakukan pengaturan administrasi keuangan pondok,

b. Sebagai jembatan sirkulasi keluar masuknya kas,

c. Mengecek semua proposal atau anggaran pengajuan dana,

d. Menyusun dan membuat laporan keuangan pondok.

\section{B. Analisis Sistem Informasi Akuntansi Pondok Pesantren di Kota Madiun}

Sistem Informasi Akuntansi yang baik dapat diketahui dengan melihat keefektifan dan keefisienan dari sistem tersebut. Untuk mengetahui tingkat keefektifan dan keefisienannya, maka perlu adanya analisis terhadap sistem tersebut. Begitu pula dengan sistem informasi akuntansi penerimaan dan pengeluaran kas pada Pondok Pesantren Kota Madiun, perlu adanya analisis atas prosedur dalam proses penerimaan dan pengeluaran kas.

a. Analisis Prosedur Penerimaan Kas

1. Iuran Wajib Syariah

Prosedur penerimaan kas dari pembayaran Syariah yaitu santri langsung menghadap pada bendahara dengan membawa kartu pembayaran Syariah, kemudian bendahara mengeluarkan bukti transaksi (kuitansi penerimaan kas), menerima uang dari santri, mengisi kartu pembayaran, memberikan paraf dan cap lunas kemudian mencatat 
transaksi tersebut pada buku daftar pembayaran administrasi bulanan, selanjunya menyimpan uang tersebut berdasarkan kriteria pembayaran. Peneliti merekomendasikan tambahan fungsi dari bagian administrasi. Jadi bendahara menerima dan menyimpan uang, dan pencatatan atas transaksi yang terjadi dilakukan oleh bagian administrasi.

2. Daftar ulang santri baru

Prosedur dalam menerima kas untuk daftar ulang santri baru ini sama dengan prosedur penerimaan kas iuran wajib Syariah.

3. Dana Hibah, sumbangan atau sedekah

Di dalam prosedur penerimaan kas dana hibah, sumbangan atau sedekah ini masih terbagi menjadi dua cara. Cara pertama dengan memberikan dana tersebut kepada bendahara dan mengikuti prosedur yang telah dijelaskan diatas. Namun untuk cara kedua dengan langsung mendatangi pengasuh kemudian memberikan dana tersebut langsung kepada pengasuh. Cara ini membuat pencatatan penerimaan kas dana hibah, sumbangan atau sedekah yang ada pada bendahara akan berbeda dengan catatan yang ada pada pengasuh.

Sehingga Peneliti merekomendasikan untuk penerimaan kas dana hibah, sumbangan atau sedekah dari masyarakat atau pihak lain diserahkan langsung kepada bendahara. Kemudian bendahara mencatat jumlahnya dalam kuitansi penerimaan rangkap 2 (1. Untuk donatur, 2. Untuk administrasi) yang ditandatangani secara sah oleh bendahara. Selanjutnya kuitansi tersebut diserahkan kepada bagian adminstrasi untuk dicatat dan diposting. Baru kemudian menyetorkan uang tersebut kepada pengasuh.

b. Analisis Prosedur Pengeluaran Kas

Di dalam pengeluaran kas ini Peneliti merekomendasikan adanya pembagian pengeluaran kas dari bendahara kedalam dua jenis pengeluaran yaitu setoran dana, dan penggunaan dana. Berikut penjelasan mengenai pembagian pengeluaran kas tersebut.

1. Setoran Dana

Merupakan jenis pengeluaran kas dari bendahara yang belum masuk ke dalam prosedur pengeluaran. Setoran dana adalah penyetoran dana dari bendahara kepada bagian tertentu, misalkan Qismut Tarbiyah, Poskestren, dan Pembangunan, yang dananya diterima oleh bendahara dari santri, kemudian disetorkan kepada bagian tersebut untuk digunakan sesuai kebutuhan operasionalnya.

i. Setoran Dana Diniyah

Merupakan setoran dana dari bendahara kepada qismut tarbiyah untuk digunakan sesuai kebutuhan operasional qista. Seperti pembelian peralatan madrasah, perlengkapan madrasah dan pemberian bisyaroh kepada para asatidz. Prosedur dalam setoran dana ini, pertama bendahara menghitung dana yang diterima atas bulan lalu untuk diniyah. Kemudian mengisi form setoran dana (lihat gambar), menyerahkannya kepada bendahara qista. Selanjutnya menandatangani form tersebut, form lembar kedua tersebut disimpan bendahara qista, lembar asli diberikan ke bagian administrasi untuk kepentingan pencatatan dan penyimpanan berkasberkas dokumen.

ii. Setoran Dana Poskes

Tidak jauh berbeda dari setoran dana diniyah, setoran ini diperuntukkan bagi operasional poskes, seperti pembelian obat-obatan, pembelian peralatan medis. Untuk prosedurnya sama dengan setoran dana diniyah. Pertamabendahar a menghitung dana yang diterima atas bulan lalu untuk poskes. Kemudian mengisi form setoran dana (lihat gambar), menyerahkannya kepada bendahara poskes. Selanjutnya menandatangani form tersebut, form lembar kedua tersebut disimpan bendahara poskes, lembar asli diberikan ke bagian administrasi.

iii. Setoran Dana Pembangunan

Sama halnya dengan setoran-setoran dana diatas, setoran ini dikhususkan untuk dana pembangunan pondok pesantren. Prosedurnya sama dengan setoran-setoran diatas. Pertama bendahara menghitung dana yang diterima atas bulan lalu untuk pembangunan. Kemudian mengisi form setoran dana (lihat gambar), menyerahkannya kepada pengasuh. Selanjutnya pengasuh menandatangani form tersebut, form lembar kedua tersebut disimpan pengasuh, lembar asli diberikan ke bagian administrasi.

2. Penggunaan Dana

Penggunaan dana adalah pengeluaran kas yang diklasifikasikan berdasarkan sumber dana yang akan dikeluarkan. Dalam hal ini terdapat tiga (3) klasifikasi, yaitu penggunaan dana Syariah, penggunaan dana listrik, dan penggunaan dana pembangunan.

i. Penggunaan Dana Syariah

Merupakan sebuah prosedur yang terjadi untuk pengeluaran kas dengan sumber dana berupa dana Syariah. Di dalam prosedur yang telah berjalan pada Pondok Pesantren Kota Madiun, dapat dikatakan masih kurang baik, transaksi dilakukan hanya pada fungsinya saja. Hal ini sangat rawan dalam kekeliruan. Prosedur yang baik yaitu prosedur dengan ditambahkannya satu fungsi, yakni bagian administrasi yang mencatat pengeluaran kas tersebut dan bagian lain mengeluarkan uang. Begitu pula dengan dokumen yang berlaku pada prosedur ini. Hanya menggunakan kuitansi yang otoritasnya tidak diketahui. 
Website : http://ekomaks.unmermadiun.ac.id/index.php/ekomaks

ii. Penggunaan Dana Listrik

Prosedur yang terjadi atas pengeluaran kas untuk pembayaran listrik, yang sumber dananya dari dana listrik yang dikhususkan untuk pembayaran keperluan listrik pondok pesantren. Sama dengan penggunaan dana Syariah di dalam prosedur ini Peneliti merekomendasikan pengisisan form bukti kas keluar untuk kebutuhan pencatatan. Untuk prosedurnya Peneliti menambahkan satu fungsi yaitu fungsi administrasi yang bertugas untuk mencatat semua pengeluaran kas dan merincikan pembayaran listrik serta merekap pembayaran listrik. Kemudian melaporkannya bersama bendahara kepada pengasuh untuk mengetahui besar pengeluaran kas untuk listrik setiap bulannya.

iii. Penggunaan Dana Pembangunan

Prosedur penggunaan dana pembangunan pada Pondok Pesantren Kota Madiun ini langsung kepada pengasuh tanpa melalui lurah pondok, sebab pihak yang bertanggung jawab secara langsung dan penuh dalam pembangunan pondok adalah pengasuh. Maka prosedur yang telah berjalan pada Pondok Pesantren di Kota Madiun dapat dikatakan telah memenuhi kriteria prosedur yang baik. Namun setelah adanya rekomendasi pada pembahasan sebelumnya, maka Peneliti juga merekomendasikan perubahan pada prosedur untuk penggunaan dana pembangunan tersebut. Pertama bagian pembangunan akan sowan kepada pengasuh dan menyerahkan proposal atau rincian anggaran yang diperlukan untuk proses pembangunan. Setelah diterima dan disetujui oleh pengasuh, maka pengasuh akan memberikan sejumlah uang yang diminta. Dan memberikan kembali proposal atau rincian anggaran tersebut untuk kemudian diserahkan ke bendahara dan bagian administrasi. Selanjutnya bagian administrasi akan mencatat segala pengeluaran yang terjadi berdasarkan bukti transaksi yang diberikan oleh bagian pembangunan. Kemudian divisi pembangunan bersama bendahara merekap semua bukti transaksi yang ada untuk membuat laporan realisasi anggaran yang nantinya akan diserahkan ke pihak ndalem atau pengasuh. Kemudian diserahkan ke administrasi untuk disimpan sebagai arsip.

\section{Laporan Keuangan}

Setelah dilakukannya evaluasi pada sistem informasi akuntansi pondok, maka peneliti bermaksud untuk merancangkan laporan keuangan Pondok Pesantren di Kota Madiun dengan menggunakan acuan PSAK 45. PSAK 45 menyebutkan bahwa komponen laporan keuangan untuk organisasi nirlaba atau yayasan terdiri dari:
a. Laporan Posisi Keuangan,
b. Laporan Aktivitas,
c. Laporan Arus Kas, dan
d. Catatan Atas Laporan Keuangan.

Berikut ilustrasi dari laporan posisi keuangan untuk Pondok Pesantren di Kota Madiun yang disajikan disesuaikan dengan PSAK 45: 


\begin{tabular}{|c|c|}
\hline $\begin{array}{r}\text { Lap } \\
\text { Yayasan Po } \\
\text { Pe }\end{array}$ & \\
\hline \multicolumn{2}{|l|}{ ASSET } \\
\hline \multicolumn{2}{|l|}{ Asset Lancar } \\
\hline Kas dan setara kas & $\operatorname{Rp} X X X$ \\
\hline Piutang & Rp XXX \\
\hline Perlengkapan & $\operatorname{Rp} X X X$ \\
\hline Total Asser Lancar & Rp XXX \\
\hline \multicolumn{2}{|l|}{ Asset Tetap } \\
\hline Tanah & Rp XXX \\
\hline Bangunan & Rp XXX \\
\hline Akum. Peny. Bangunan & $\operatorname{Rp}(X X X)$ \\
\hline Peralatan & Rp XXX \\
\hline Akum. Peny. Peralatan & $\operatorname{Rp}(X X X)$ \\
\hline Total Asset Tetap & Rp XXX \\
\hline Total Asset & Rp XXX \\
\hline \multicolumn{2}{|l|}{ LIABILITAS } \\
\hline Liabilitas Jangka Pendek & $\operatorname{Rp} X X X$ \\
\hline Total Liabilitas Jangka Pendek & Rp XXX \\
\hline \multicolumn{2}{|l|}{ ASSET NETTO } \\
\hline Tidak Terikat & Rp XXX \\
\hline Terikat Temporer & Rp XXX \\
\hline Terikat Permanen & Rp XXX \\
\hline Total Liabilitas dan Aset Neto & Rp XXX \\
\hline
\end{tabular}

\section{IV.KESIMPULAN DAN SARAN}

\section{A. Kesimpulan}

Sistem informasi akuntansi merupakan suatu sistem yang dibuat oleh manusia yang terdiri dari komponen-komponen dalam organisasi untuk mencapai sebuah tujuan yaitu penyajian informasi. Oleh sebab itu penggunaan sistem informasi pada pondok pesantren sangatlah dibutuhkan selain menambah efektifitas dan efisiensi operasional keuangan pesantren juga sebagai sarana membantu proses pelaporan pertanggungjawaban bantuan yang diberikan. Informasi yang dihasilkan oleh sistem informasi akuntansi memegang peranan yang penting. Sistem informasi akuntansi itu sendiri dapat digunakan untuk sarana pengawasan, pengendalian, dan pengaturan segala aktifitas dan kegiatan operasional keuangan pondok pesantren agar berjalan sesuai dengan apa yang telah ditetapkan.

Penelitian ini memiliki tujuan umum yakni untuk mengetahui bagaimana sistem yang baik bagi pesantren. Sedangkan tujuan khusus penelitian ini adalah untuk mengetahui rancangan sistem informasi akuntansi pada Pondok Pesantren di Kota Madiun. Berdasarkan hasil dari observasi dan wawancara serta analisis yang telah diuraikan, Peneliti menyimpulkan sebagai berikut :

1. Prosedur yang diberlakukan dalam setiap proses transaksi baik penerimaan kas maupun pengeluaran kas dapat dikatakan cukup baik, hanya masih belum dikatakan sesuai dengan ketentuan yang berlaku bagi organisasi nirlaba. Dalam pembagian tugas dari struktur organisasi sudah jelas, hanya pada bagian keuangan belum dipisahkan fungsi dari bagian administrasi dan bagian pembawa kas. Begitu pula dengan dokumen yang diperlukan dalam setiap transaksi, masih belum memiliki dokumen tersendiri sehingga perlu adanya pembagian dokumen berangkap 2 atas setiap transaksi yang terjadi supaya dapat terjadi saling mengecek dan tidak terjadinya salah entry.

2. Laporan keuangan dalam Pondok Pesantren di Kota Madiun masih menggunakan pembukuan, sehingga dalam pencatatan setiap transaksi masih menggunakan single entry, dan tidak memperhatikan pengaruh dari setiap transaksi yang terjadi ke akun yang telah ada.

3. Proses bermuamalah yang dijalankan oleh Pondok Pesantren di Kota Madiun telah dilakukan dengan cara yang baik, dan secara adil, hanya saja masih kurang professional dalam proses muamalah yang terjadi, sebab belum adanya seseorang yang faham tentang ilmu akuntansi sehingga dalam proses bermuamalah nanti akan berjalan secara adil dan professional. 
Website : http://ekomaks.unmermadiun.ac.id/index.php/ekomaks

\section{B. Saran}

Berdasarkan hasil observasi dan wawancara serta analisis yang telah diuraikan, Peneliti menyarankan sebagai berikut :

1. Penelitian selanjutnya diharapkan untuk dapat meneliti bagaimana proses implementasi sistem informasi akuntansi yang terdapat pada Pondok Pesantren di Kota Madiun.

2. Untuk peneliti selanjutnya diharapkan dapat mengevaluasi hasil penelitin kami agar Pondok Pesantren di Kota Madiun dapat berkembang lebih baik lagi dalam administrasi dan laporan keuangan.

\section{DAFTAR PUSTAKA}

Arikunto, Suharsimi. (2006). "prosedur penelitian. PT.Rineka Cipta. Jakarta.

Alter, S. 1992. Information System: A Management Perspective. The Benjamin/ Cumming Publishing. Company, Inc.

Arikunto, Suharsimi. 2010. Prosedur Penelitian. Jakarta: PT. Rineka Cipta Bodner George \& Hopwood William S. 2001. Sistem Informasi Akuntansi, Salemba Empat. Jakarta

-----. (2001)). Accounting Information System eigth edition, Prentice Hall, Inc., Deddy Jacobus., Anggota IKAPI.Sistem Informasi Akuntansi. Jakarta: PT Indeks Kelompok Gramedia

Daranatha, S. 2009. Sistem Informasi Akuntansi, Salemba Empat, Jakarta.

Hall, James A. (2001). Sistem Informasi Akuntansi. Terjemahan Jusuf, Salemba Empat, Jakarta.

----. (2007). Sistem Informasi Akuntansi, Edisi 3, terjemahan Amir Abadi Yusuf. Jakarta: Salemba Empat

----. (2009). Sistem Informasi Akuntansi. Jakarta: Salemba Empat

Husein, M. F., 2004. Sistem Informasi Akuntansi, Penerbit UPP AMP YKPN, Yogyakarta.

Krismiaji. (2002). Sistem Informasi Akuntansi. Unit Penerbit dan Percetakan AMP YKPN. Yogyakarta.

Jogiyanto. 2000. Sistem Informasi Akuntansi Berbasis Komputer. Edisi ketiga. Yogyakarta : BPFE

Kahubung, Merysantika. 2013. Sistem informasi akuntansi penerimaan dan pengeluaran kas untuk perencanaan dan pengendalian keuangan pada Organisasi nirlaba keagamaan. Jurnal Riset Ekonomi, Manajemen, Bisnis dan Akuntansi. Diperoleh tanggal 14 Agustus 2019 dari http://ejournal.unsrat.ac.id/index.php/emba/article/view/1832

Mahmudi. (2009). Sistem Akuntansi Organisasi Pengelola Zakat. Yogyakarta: P3EI Press.

Mcleod, Raymond, Jr. (2001) “Sistem Informasi Manajemen”, Penerbit Prenhallindo, Jakarta.

Mulyadi. 2008. Sistem Akuntansi, STIE YKPN, Yogyakarta

-----, 2010. Sistem Akuntansi, Edisi Ketiga Penerbit Salemba Empat, Jakarta Moloeng, Lexy. 2010. Metodologi Penelitian Kualitatif. PT. Remaja Rosdakarya. Bandung.

Narko. 2007. Sistem Akuntansi. Edisi Kelima. Penerbit: Yayasan Pustaka Nussntara. Yogyakarta.

Nugroho Widjajanto. 2001. Sistem Informasi Akuntansi, Jakarta : Erlangga, STIE Trisakti

Republik Indonesia. Undang-undang Nomor 20 Tahun 2003 tentang Sistem Pendidikan Nasional. Sekretariat Negara. Jakarta.

Rizky, Diyani Ade dan Padmono, Yazid Yud. (2013). Analisis Penerapan PSAK No. 45 pada Yayasan Masjid Al Falah Surabaya. Jurnal Ilmu \& Riset Akuntansi Vol.2 No.7. Diperoleh tanggal 15 Agustus 2019 dari https://ejournal.stiesia.ac.id/jira/article/viewFile/154/163

Romney, Marshall B. 2006. Sistem Informasi Akuntansi, Edisi 9, Buku 1, Salemba Empat, Jakarta.

Shihab, M. Quraish.(2003). Tafsir AL-Misbah. Jakarta: Lentera Hat

Wahyono, Teguh. (2004). Sistem Informasi Konsep Dasar, Analisis Desain dan Implementasi, Penerbit Graha Ilmu. Yogyakarta.

Warren, Carl.S, Reeve, James.M, Fess, Philip.E. 2008. Pengantar Akuntansi. Penerbit Salemba Empat Jakarta.

Widjajanto, Nugroho.(2001). Sistem Informasi Akuntansi. Jakarta: Erlangga 